\title{
PERANCANGAN PUSAT AQUATIC CENTRE DENGAN PENDEKATAN ARSITEKTUR ORGANIK DI BOGOR
}

\author{
Abdul Rohman $^{1}$, Asri Budiarto ${ }^{2}$, Wiyoga Triharto ${ }^{3}$ \\ ${ }^{1}$ Universitas Indraprasta PGRI, Program Studi Arsitektur \\ abdulrohman_05@yahoo.com \\ ${ }^{2}$ Universitas Indraprasta PGRI, Program Studi Arsitektur \\ asribudiarto@gmail.com \\ ${ }^{3}$ Universitas Indraprasta PGRI, Program Studi Arsitektur \\ wiyogatriharto@yahoo.com
}

\begin{abstract}
One example of sports is water sports. Water or aquatic sports are various forms of water activities that can be done in rivers, lakes, seas, beaches, or swimming pools. The forms of sports or activities include swimming, diving, water polo, and various other forms (Susanto, 2014). There fore, in general sports, it is necessary to review and re-plan sports facilities that are not suitable for use. From the existing problems the author will try to plan an Aquatic Center. Facilities-facilities that have a standard for competition can affect achievement. At the city scale, spaces that are utilized as integrated sports areas also function as a counterweight to the urban environment. There fore, the demand for providing sports facilities to the public is so important to a city given the nature of the activities and spaces created from sports activities act as a counterweight both for human daily activities and for the balance of the urban environment. How to create an Aquatic Center center and design forms for visitors with all existing activities according to other special needs with an organic architectural approach. The goal is as a place or place for swimming sports centers for athletes and the community to improve performance and health both in terms of sports and recreation so as to improve the quality of life of the community.
\end{abstract}

Keywords: Design, Aquatic Center, Organic Architecture

\begin{abstract}
Abstrak. Salah satu contoh cabang olahraga yaitu cabang olahraga air. Olahraga air atau akuatik merupakan berbagai macam bentuk aktivitas air yang dapat dilakukan di sungai, danau, laut, pantai, maupun kolam renang. Adapun bentuk olahraga atau kegiatannya antara lain renang, loncat indah, polo air, dan beragam bentuk lainnya (Susanto, 2014). Dari permasalahan yang ada Penulis akan mencoba untuk merencanakan sebuah Aquatic Centre. Fasilitas sarana yang memiliki standar untuk kompetisi dapat mempengaruhi prestasi. Pada skala kota, ruang-ruang yang dimanfaatkan sebagai area olahraga terpadu juga berfungsi sebagai penyeimbang lingkungan perkotaan, Karena itu tuntutan penyediaan fasilitas olahraga bagi publik menjadi begitu penting terhadap suatu kota mengingat sifat dari aktivitas dan ruang-ruang yang diciptakan dari aktivitas olahraga berperan sebagai penyeimbang baik bagi aktivitas keseharian manusia maupun bagi keseimbangan lingkungan perkotaan. Bagaimana menciptakan sebuah pusat Aquatic Center dan bentuk desain untuk para pengunjung dengan segala aktivitas yang ada sesuai dengan kebutuhan- kebutuhan khusus lainnya dengan pendekatan arsitektur organik. Tujuannya yaitu sebagai wadah atau tempat pusat olahraga renang para atlet dan masyarakat untuk meningkatkan prestasi dan kesehatan baik dari sisi olahraga dan rekreasi sehigga meningkatkan kualitas hidup masyarakat.
\end{abstract}

Kata Kunci : Perancangan, Pusat Akuatik, Arsitektur Organik

\section{PENDAHULUAN}

Pada skala kota, ruang-ruang yang dimanfaatkan sebagai area olahraga terpadu juga berfungsi sebagai penyeimbang lingkungan perkotaan, Karena itu tuntutan penyediaan fasilitas olahraga bagi publik menjadi begitu penting terhadap suatu kota mengingat sifat dari aktivitas dan ruang-ruang yang diciptakan dari aktivitas olahraga berperan sebagai penyeimbang baik bagi aktivitas keseharian manusia maupun bagi keseimbangan lingkungan perkotaan.

Mengembangkan olahraga renang baik untuk membangun kan kembali melihat olahraga renang dan mengembangkan potensi-potensi muda yang memilki bakat renang serta mampu untuk membantu meningkatkan kualitas fisik masyarakat. Berdasarkan hal-hal yang telah diuraikan diatas, demi menunjang perkembangan 
olahraga renang dan sejenisnya di Indonesia, perlu adanya sebuah sarana yang dapat memotivasi para atlet utuk lebih rajin berlatih, menguatkan mental mereka, dan membangkitkan kecintaan mereka terhadap indonesia.

Menciptakan sebuah pusat Aquatic Center di Bogor dan bentuk desain untuk para pengunjung dengan segala aktivitas yang ada sesuai dengan kebutuhan-kebutuhan khusus lainnya dengan pendekatan arsitektur organik. Arsitektur organik sendiri ialah arsitektur yang menitikberatkan pada harmoni antara tempat tinggal manusia dan alam. Sehingga desan desain yang diciptakan menyatu dengan tapak dan lingkungan sekitarnya. Pada arsitektur organik bentuk bangunan dan tapak adalah satu hal yang terpadu. Sehingga harus selaras antara tapak dan bangunan.

Dari permasalahan yang ada Penulis akan mencoba untuk merencanakan sebuah Aquatic Centre. Fasilitas sarana yang memiliki standar untuk kompetisi dapat mempengaruhi prestasi. Berdasarkan hasil olah cepat pencacahan Sensus Penduduk 2017, diketahui jumlah penduduk di Kota Bogor mencapai 1.081.009 jiwa. Penduduk berjenis kelamin kali-laki masih yang mendominasi, yakni mencapai 484.648 jiwa. Sedangkan penduduk perempuan mencapai 464.418 jiwa. Dengan persentase jumlah penduduk perempuan 532.813 dan penduduk laki-laki 548.196 sedangkan lebih dari 25\% terdiri dari usia 10-24 merupakan usia produktif guna pencarian bibit-bibit unggal dibidang olahraga. Seperti tabel di bawah ini:

Tabel 1 Jumlah Penduduk Menurut Kelompok Umur dan Jenis Kelamin di Kota Bogor, 2017

\begin{tabular}{|c|c|c|c|}
\hline Kecamatan & \multicolumn{3}{|c|}{ Jenis Kelamin/Sex } \\
\hline Sub Districts & Laki-laki/Male & Perempuan/Female & Jumlah/Total \\
\hline \multicolumn{4}{|c|}{} \\
\hline $0-4$ & 49,087 & 46,050 & 95,137 \\
\hline $5-9$ & 46,893 & 44,166 & 91,059 \\
\hline $10-14$ & 43,715 & 42,033 & 85,748 \\
\hline $15-19$ & 47,618 & 48,045 & 95,663 \\
\hline $20-24$ & 51,753 & 49,732 & 101,485 \\
\hline $25-29$ & 48,521 & 46,336 & 94,857 \\
\hline $30-34$ & 46,168 & 43,835 & 90,003 \\
\hline $35-39$ & 44,017 & 43,259 & 87,276 \\
\hline $40-44$ & 41,515 & 40,265 & 81,780 \\
\hline $45-49$ & 35,776 & 34,813 & 70,589 \\
\hline $50-54$ & 30,336 & 29,554 & 59,890 \\
\hline $55-59$ & 24,052 & 23,440 & 47,492 \\
\hline $60-64$ & 16,068 & 14,690 & 30,758 \\
\hline $65-69$ & 10,098 & 10,468 & 20,566 \\
\hline $70-74$ & 6,382 & 7,246 & 13,628 \\
\hline $75+$ & 6,203 & 8,881 & 15,084 \\
\hline Jumlah/Total & 548,196 & 532,813 & $1,081,009$ \\
\hline
\end{tabular}

Dari permasalahan yang ada, Penulis akan mencoba merencanakan sebuah Aquatic Centre yang nantinya dapat menjadi wadah atau tempat pusat olahraga renang para atlet dan masyarakat untuk meningkatkan prestasi dan kesehatan baik dari sisi olahraga dan rekreasi sehigga meningkatkan kualitas hidup masyarakat.

\section{METODOLOGI}

Pada tahapan ini dilakukan dengan analisa data menggunakan metode analisis deskriptif yaitu melalui penguraian data-data yang disertai gambar sebagai media berdasar pada teori normatif yang ada. Tahapan analisa akan dilakukan pengolahan data-data yang telah terkumpul dan dikelompokan berdasarkan pemrograman fungsional, performansi, dan arsitektural.

Metode perancangan yang digunakan untuk merancang bangunan Aquatik Centre dipilih berdasarkan beberapa aspek permasalahan diantaranya : Masalah massa, ruang, tampilan, pengolahan site, utilitas, dan struktur bangunan yang menyatukan akan tuntutan kebutuhan pengguna dengan persyaratan yang ada.

\section{HASIL DAN PEMBAHASAN}

Untuk memecahkan masalah diatas, penggunaan metode perancangan arsitektur organik menggunakan konsep perancangan programatik pada Pusat Aquatic Centre di Bogor mencakup proses analisa dan sintesa arsitektural akan dihasilakan beberapa konsep fungsional, konsep perancangan tapak, konsep perancangan tata ruang, konsep perancangan pengkondisian ruang, konsep perancangan struktur dan konstruksi, konsep perancangan utilitas bangunan, dan konsep kelengkapan bangunan.

\section{Preseden}

\section{London Aquatics Centre}

London Aquatics Centre adalah salah satu fasilitas renang paling canggih dan paling menakjubkan di dunia dan rumah dari London Legacy 2012, Queen Elizabeth Olympic Park. Pada 2012, Pusat Akuatik London yang spektakuler, yang dirancang oleh arsitek Zaha Hadid dan S\&P, memberikan latar belakang bagi 
rekor dunia yang tak terhitung jumlahnya. Tempat ini terdiri dari berbagai fasilitas untuk mengakomodasi semua pengunjung. Ada tiga kolam renang, kolam kompetisi 50 meter, kolam pelatihan 50 meter, dan yang ketiga adalah kolam menyelam dengan platform di $1 \mathrm{~m}-10 \mathrm{~m}$. Selain itu, London Aquatics Centre menyediakan gym modern, fasilitas menyelam kering, dan fasilitas ganti ramah keluarga.

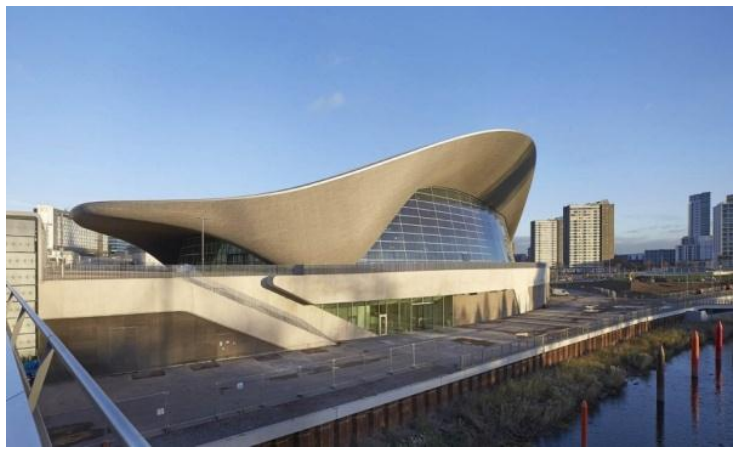

Gambar 1. London Aquatics Centre

(Sumber: google.com)

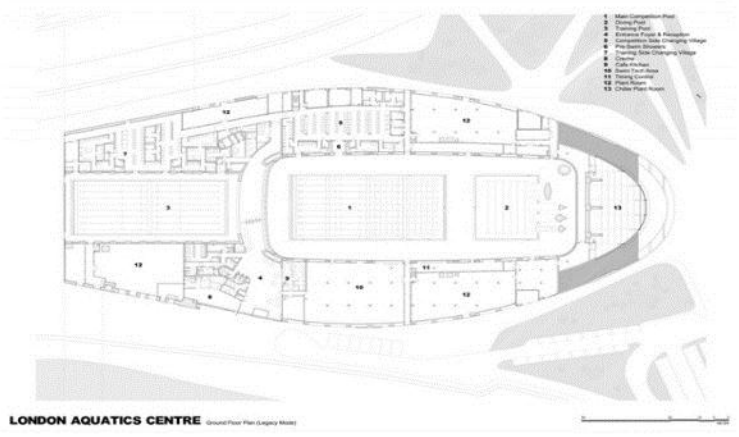

Gambar 2 Site Plan London Aquatics Centre (Sumber: archimagazine.com)

\section{Lokasi}

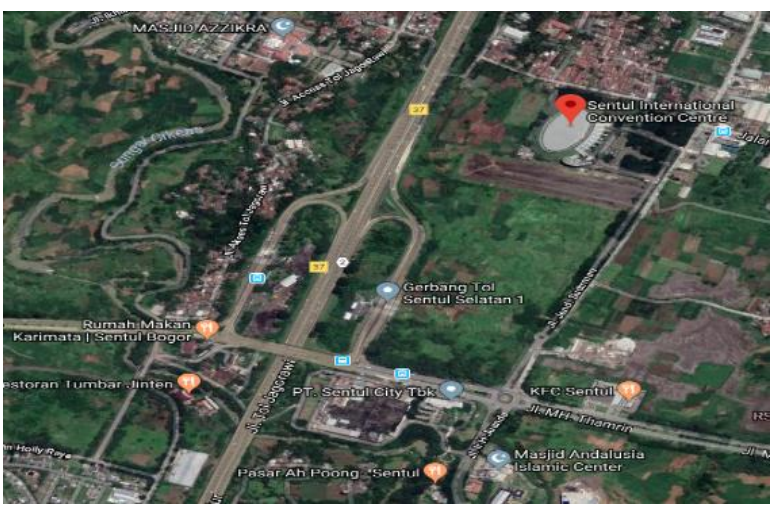

Gambar 3. Lokasi site pilihan

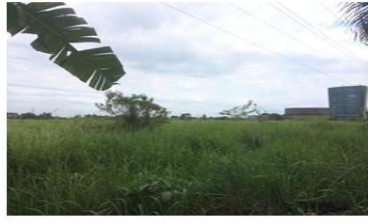

Tampak Arah Utara

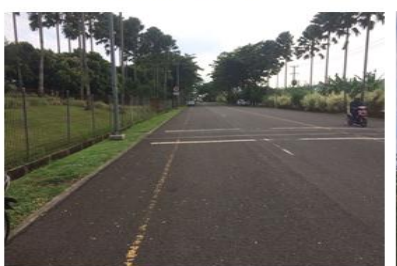

Tampal: Arah Selatan

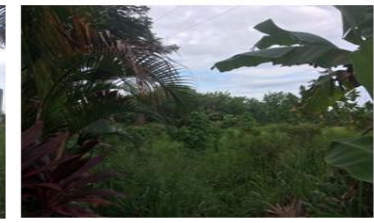

Tampak Arah Bara

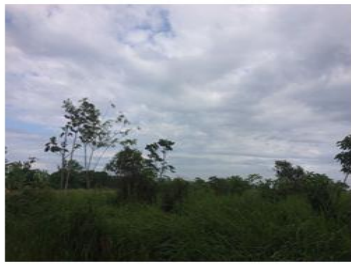

Tampal: Arah Timur
Gambar 4. Foto Lapangan Eksisting

Keterangan :

1. Utara : Tapak berbatasan dengan Gedung Sentul International Convention Center, menjadikan sarana berolahraga renang dan refresing bagi pengunjung acara di convention.

2. Selatan: Tapak berbatasan dengan jalan dan Mall Belanova Sentul, membantu pusat perbelanjaan bagi pengunjung aquatic centre.

3. Timur : Tapak berbatasan dengan jalan dan pemukiman warga, tujuan dan sasaran dari aquatic centre.

4. Barat : Tapak barat site berbatasan dengan jalan Jl. Tol Jagorawi, sehingga aksessibilalitas sangat mendukung bagi pengunjung dari luar kota.

Lokasi : Jl. Jenderal Sudirman, Babakan Madang, Cipambuan, Babakan Madang, Bogor, Jawa Barat 16810

$\begin{array}{ll}\text { Luas Lahan } & : 10 \text { Hektare }\left(100.000 \mathrm{~m}^{2}\right) \\ \text { KDB } & : 40 \% \\ \text { KLB } & : 1.5 \\ \text { RTH } & : 60 \%\end{array}$

\section{Zoning}

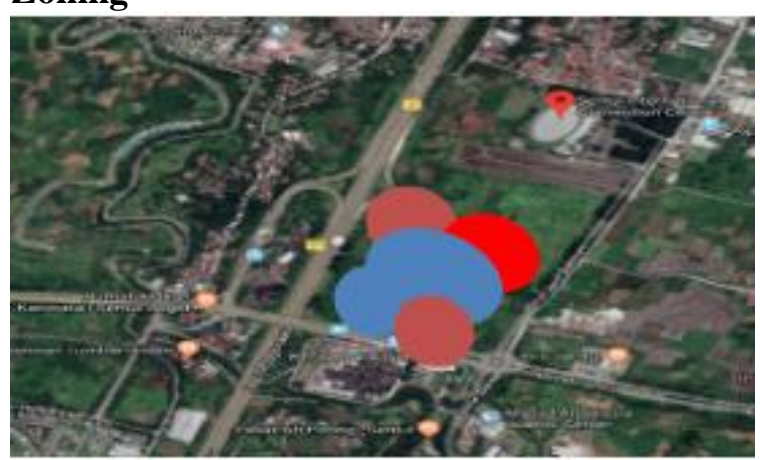

Gambar 5. Zoning Analisa 
Keterangan :

\section{: Zona Publik \\ : Zona Semi Publik \\ : Zona Privat}

Penzoningan pada tapak di sesuaikan dengan keutuhan ruang dimana sifat ruang privat tidak berhubungan langsung melainkan dibatasi oleh semi publik dimana tidak semua orang di perbolehkan masuk tanpa ijin pengelola.

\section{Gubahan Massa}

Proses dalam perancanaan aquatic centre ini mendapatkan ide gubahan masa dari binatang air yaitu ikan, sebagai bentuk massa bangunan sebagai berikut :

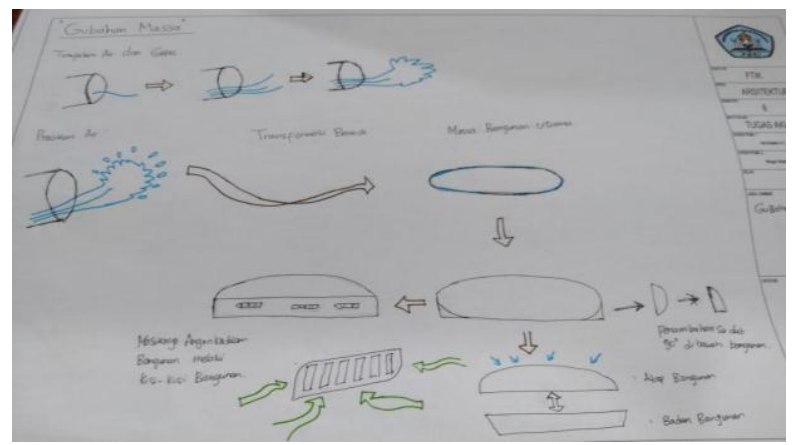

Gambar 6. Bentuk Gubahan Massa

\section{Orientasi Ruang}

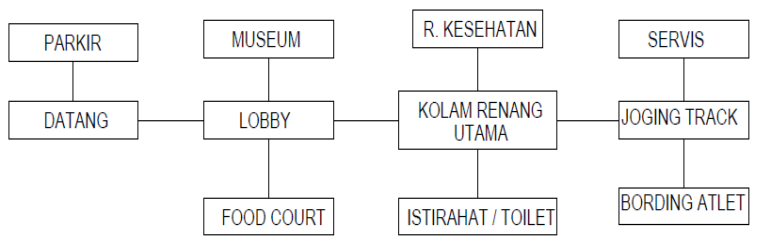

Gambar 7. Orientasi Ruang

\section{HubunganRuang Makro:}

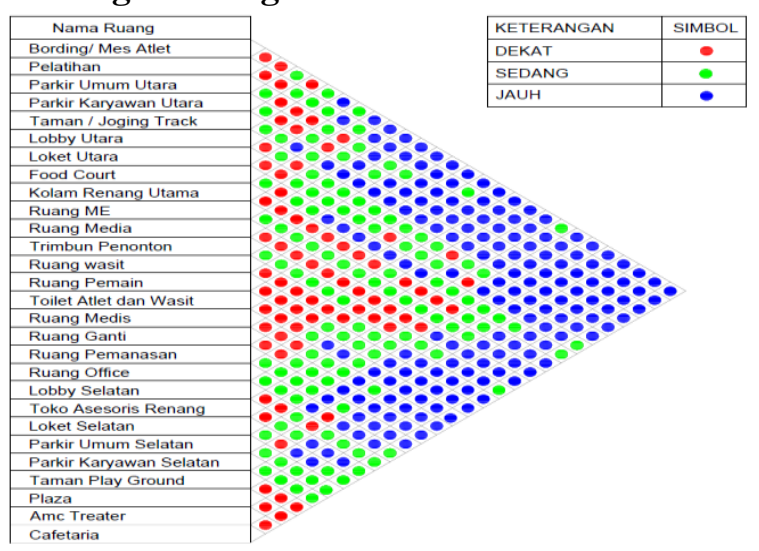

Gambar 8. Hubungan Ruang

\section{Diagram Bubbel Ruang:}

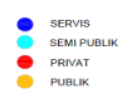

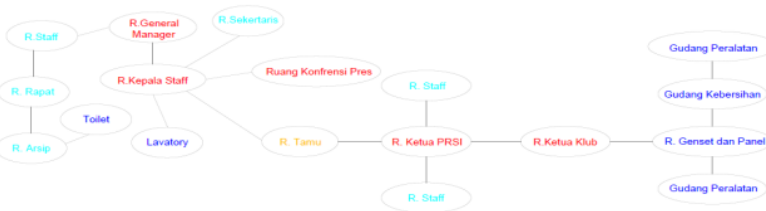

Gambar 9. Bubbel Zona 1(area pemain dan pengelola)

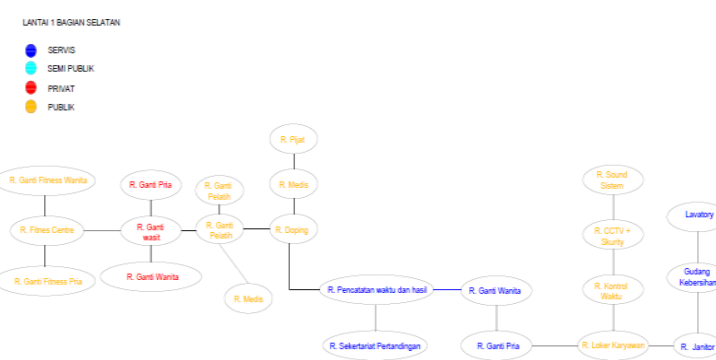

Gambar 10. Bubbel Zona 2 area pemain dan pengelola

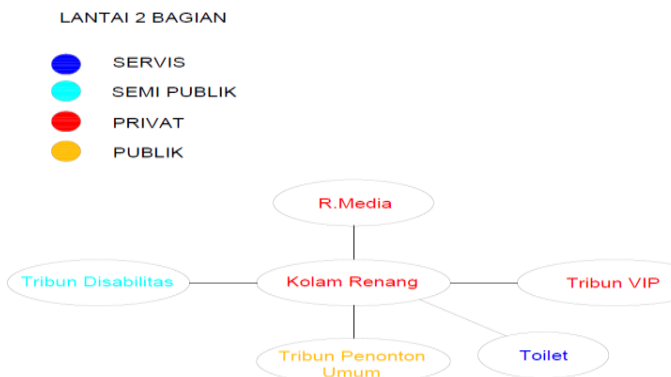

Gambar 11. Bubbel Zona lantai 2 (area tribun)

Site

Plan

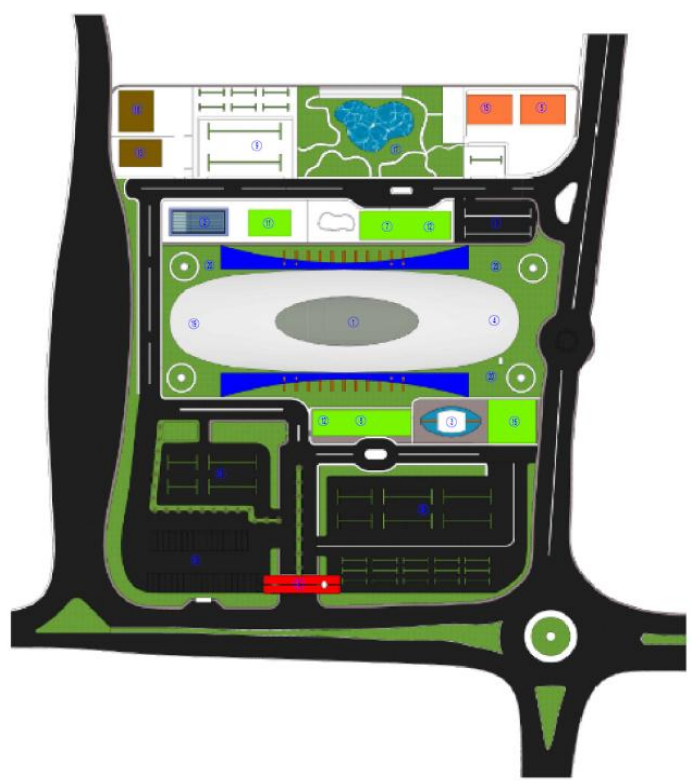


Gambar 12. Site Plan

\section{Keterangan Site Plan:}

1. Bangunan Aquatic Centre

2. Kolam Pemanasan

3. Food Court

4. Filterisasi Air Kolam

5. Bording Atlet

6. Gerbang Pintu Masuk Utama

7. Lobby Utara dan Loket

8. Lobby Selatan dan Loket

9. Parkir Umum Utara

10.Parkir Umum Selatan

11.Ruang Ganti Kolam Pemanasan

12.Mini Market

13.Ruang ME

14.Parkir Karyawan

15.Ruang Pelatihan Atlet Renang

16.Cafétaria

17. Taman Anak-anak dan Joging Track

18.Pengelolahan Sampah

19.Ruang Apresiasi

20.Plaza

Dalam penataan site plan dalam bangunan olahraga, area parkir penggunjung sangat di jauhkan dengan area bangunan utama, di karenakan mencegah terjadi sebuah kericuhan dalam acara pertandingan. Sementara ruangruang privat di letakan di belakang, agar akses ruang privasi tidak bisa di jangkau bagi pengunjung umum.

\section{Denah Aquatic Centre}

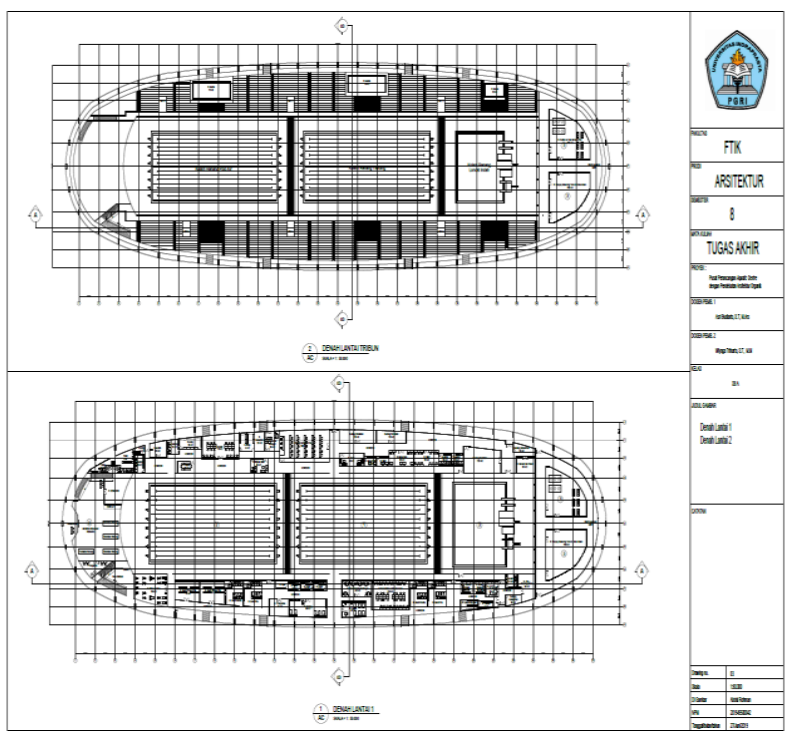

Gambar 13. Denah
Proses penatan zonasi denah di bagi menjadi dua yaitu area bawah untuk pengelola dan atlet dan area atas untuk penonton dan tamu undangan.

\section{Tampak}

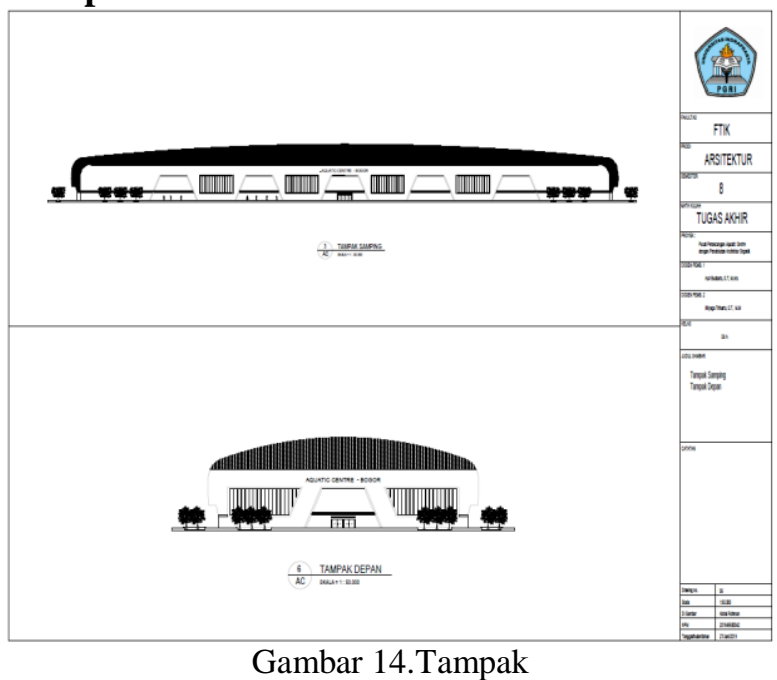

Penggunaan fasad pada bangunan di buat dengan menggunakan selasar kisi-kisi, supaya angin atau udara dari luar bisa masuk melalui kisi-kisi tersebut dengan ukuran yang sudah di tentukan.

\section{Potongan}

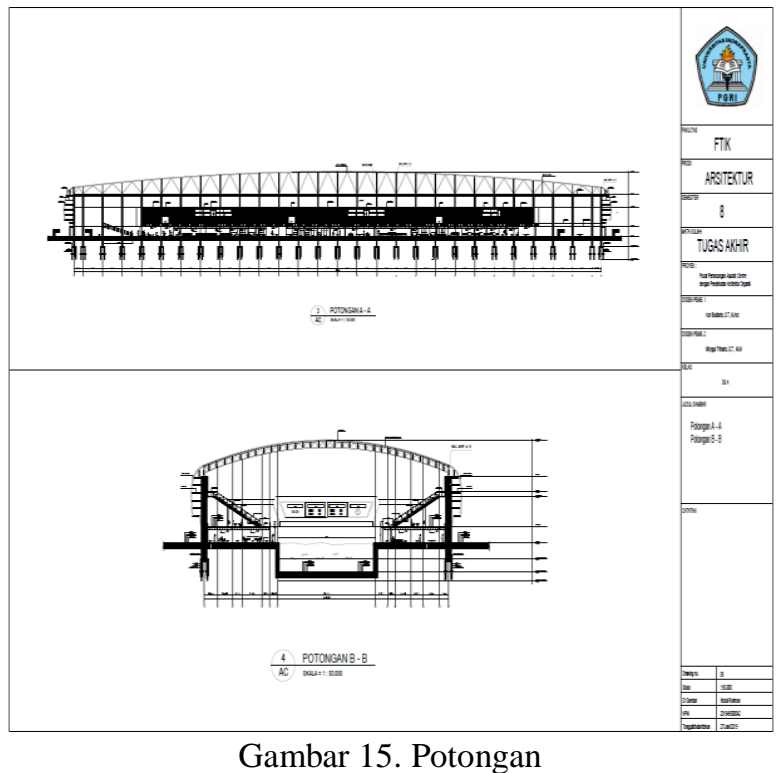

Dalam potongan bangunan terdapat bagian yang harus di buat yaitu penyandang keterbatasan atau diafabel maka dalam zona 2 di kasih ram supaya penyandang diafabel bisa mengakses. Material yang di pakai dalam pembuatan atap menggunakan space frame, 
sedangkan penutup atap namanya trimdek lapisan baja yang bisa bertahan lama dan lapisan tersebut yaitu kain panel.

\section{Perspektif Eksterior}
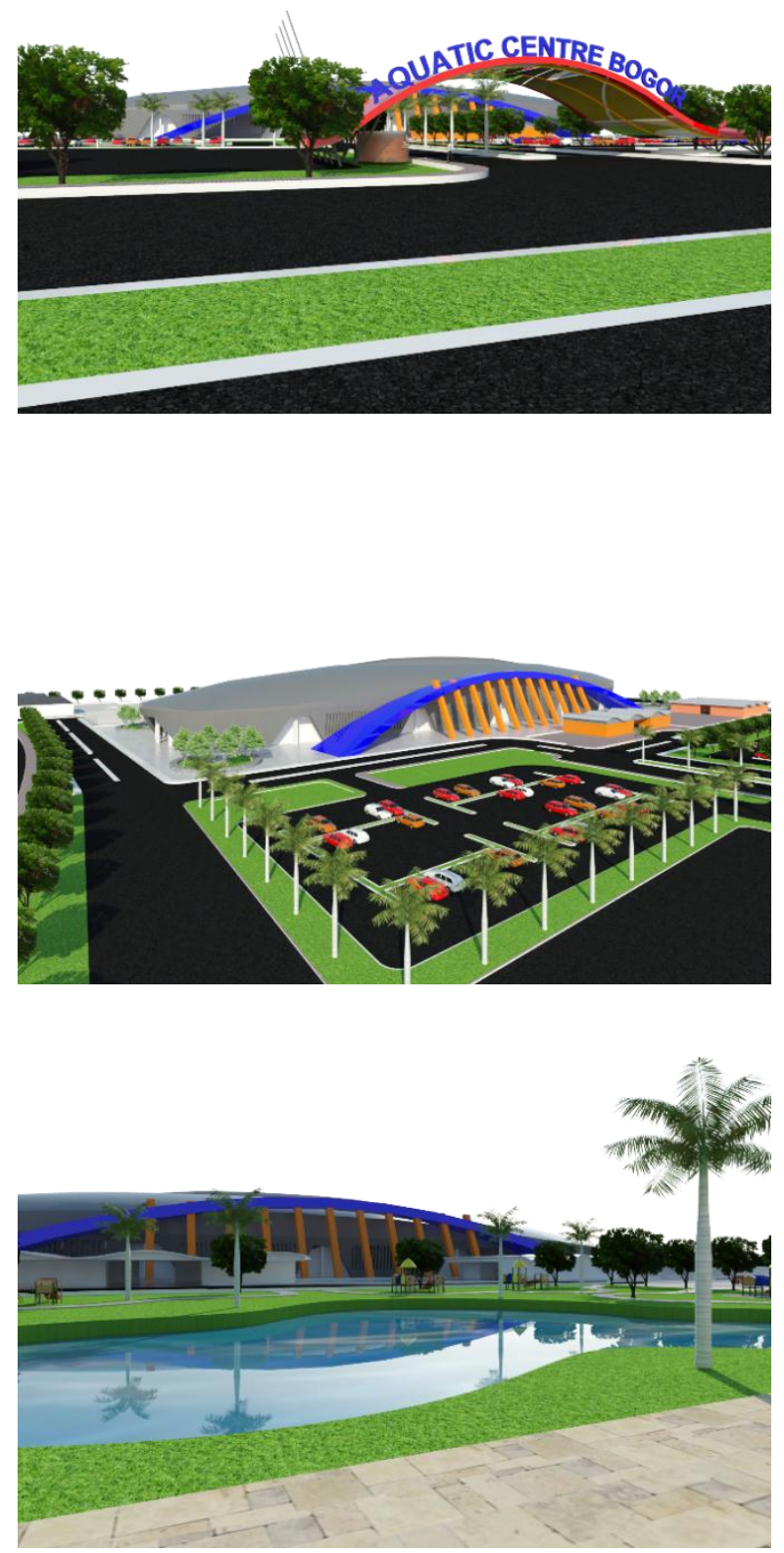

\section{Perspektif Interior}

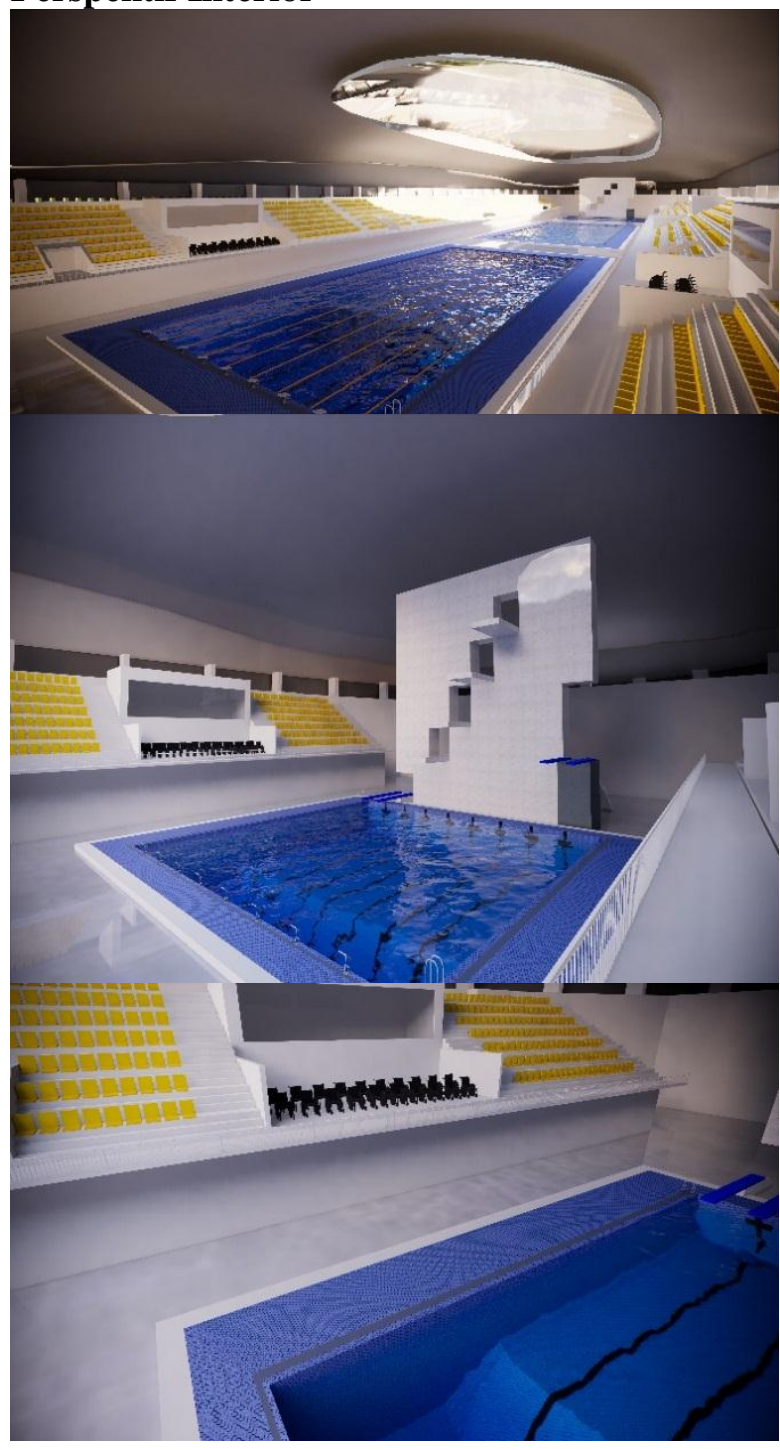

\section{PENUTUP}

Simpulan

Perancangan Aquatic Center dalam pemilihan tapak sangat strategis karena site perancangan berada berbatasan dengan gedung Sentul Convention Center, Mall Belanova, jalan tol Sentul, serta area pemukiman warga sehingga akses menuju site sangat mudah dijangkau oleh masyarakat. Penzoningan pada tapak di sesuaikan dengan kebutuhan ruang dimana sifat ruang privat tidak berhubungan langsung melainkan dibatasi oleh semi publik karena tidak semua orang di perbolehkan masuk tanpa ijin pengelola. 


\section{Saran}

Dalam mendesain perlu mempertimbangkan beberapa faktor dari segi kenyamanan pengguna dan lingkungan, sehingga selaras dengan konsep yang dibuat yaitu organik identik dengan tumbuh.

Lokasi yang strategis dapat memberikan suatu rancangan yang baik sesuai dengan aksesibilitas dan konsep pendekatan yang sesuai dalam suatu lingkungan.

\section{DAFTAR PUSTAKA}

\section{Buku}

FINA. 2015. FINA Handbook 2013-2017. Swiss: FINA Federation Internationale de Natation.

Neufert, Ernst. 1991. Data Arsitek Jilid II Edisi Kedua. Erlangga. Jakarta

Kantor Menpora. 1994. StandarSNI 03-36471994 tentang Tata Cara Perencanaan Teknik Bangunan Gedung Olahraga. Jakarta.

Kantor Menpora. 1997. StandarSNI T-27-199103 tentang Tata Cara Perencanaan Teknik Bangunan Kolam Renang. Jakarta. Saddly, (1993) Hasan, Kamus Inggris, Indonesia. Neufert, Ernst. 1996, "Data Arsitek Jilid 1", Erlangga, Jakarta

Panero, Julius. 2003. "Dimensi Ruang \& Raung Interior", Erlangga, Jakarta

White, Edward T. 1994. "Analisis Tapak", Intermatra, Jakarta

White, Edward T. 1995. "Sumber Konsep", Intermatra, Jakarta

Callender, john Hancock. 1973. Time-Saver Standards For Building Types. New York: Mc. Graw Hill Book Company

Dreiseitl, Herbert. 2005. New Waterscapes. Basel: Birkhauser.PDF Ice rinks and Swimming pools, Greint john

\section{Referensi Internet}

(https://bogorkota.bps.go.id/statictable/2018/10/1 8/193/indeks-pembangunan-manusiakota-bogor-dan-jawa-barat-persen-20132017.html. Diakses pada tanggal 01 April 2019)
London Aquatics Centre for. 2012. "Summer Olympics / Zaha Hadid Architects." (http://www.archdaily.com/161116/londo n-aquatics-centre-for-2012-summerolympics-zaha-hadid-architects/. Diakses pada tanggal 15 April 2019)

FINA. 2015. FINA Sports History. (http://edupaint.com/eksterior/garasi/7225beberapa-konsep-dasar-arsitekturorganik.html. Diakses pada 05 Mei 2019). 